\title{
Effect of injectable vitamin $E$ on incidence of retained fetal membranes and reproductive performance of dairy cows
}

\author{
G. C. S. Pontes, ${ }^{*}$ P. L. J. Monteiro Jr., ${ }^{*}$ A. B. Prata, ${ }^{*}$ M. M. Guardieiro, ${ }^{*}$ D. A. M. Pinto, ${ }^{*}$ G. O. Fernandes, ${ }^{*}$ \\ M. C. Wiltbank, ${ }^{*} \dagger$ J. E. P. Santos, $\ddagger$ and R. Sartori*1 \\ *Department of Animal Sciences, University of São Paulo, Escola Superior de Agricultura Luiz de Queiroz, Piracicaba, Brazil 13418-900 \\ †Department of Dairy Sciences, University of Wisconsin, Madison 53706 \\ ‡Department of Animal Sciences, University of Florida, Gainesville 32611-0910
}

\section{ABSTRACT}

The objectives were to evaluate the effects of injectable vitamin $\mathrm{E}$ during the last $3 \mathrm{wk}$ prepartum on the incidence of retained fetal membranes (RFM) and reproductive performance. Dairy cows $(\mathrm{n}=890), 390$ Holsteins (132 nulliparous and 258 parous) and 500 crossbred Holstein × Gyr (199 nulliparous and 301 parous), from 3 dairy farms in Brazil were assigned to the study. In all 3 farms, from October to March, prepartum cows grazed tropical grasses and received $2 \mathrm{~kg} / \mathrm{d}$ of a mixture of finely ground corn, soybean meal, and minerals and vitamins. From April to September prepartum cows received a total mixed ration composed of corn silage, finely ground corn, soybean meal, and minerals and vitamins. During the prepartum period, cows were fed 280 (farm 1), 390 (farm 2 ), and $480 \mathrm{IU}$ (farm 3) of supplemental vitamin E per day, and throughout postpartum, cows were fed 370 (farm 1), 500 (farm 2), and 600 (farm 3) IU of supplemental vitamin E. Within each farm, cows were randomly assigned to remain as untreated controls or to receive 3 i.m. injections of 1,000 IU each of DL- $\alpha$ tocopherol administered at $19.2 \pm 4.3,12.9 \pm 3.3$, and $6.2 \pm 2.9 \mathrm{~d}$ before calving (VitE). Blood was sampled from 141 cows immediately before enrollment to determine the $\alpha$-tocopherol and cholesterol statuses. Blood was also sampled and analyzed for concentrations of cortisol and nonesterified fatty acids in the last $3 \mathrm{wk}$ of gestation. The serum concentration of $\alpha$-tocopherol or $\alpha$-tocopherol:cholesterol ratio did not differ between treatments and averaged $2.97 \pm 0.10 \mu \mathrm{g} / \mathrm{mL}$ and 4.46 $\pm 0.16 \times 10^{-3}$, respectively. In total, $53.2 \%$ of the cows had an inadequate concentration of serum $\alpha$-tocopherol based on the $3.0 \mu \mathrm{g} / \mathrm{mL}$ cut-off for adequacy. The risk of RFM decreased as serum $\alpha$-tocopherol increased.

Received September 22, 2014.

Accepted January 6, 2015.

${ }^{1}$ Corresponding author: robertosartori@usp.br
Milk production did not differ between controls and VitE cows. Treatment with injectable $\alpha$-tocopherol decreased RFM from 20.1 to $13.5 \%$, decreased incidence of stillbirth from 14.9 to $6.8 \%$, and tended to decrease death by $200 \mathrm{~d}$ postpartum. VitE cows tended to have improved pregnancy per insemination at first AI (36.7 vs. $30.1 \%$ ) because of decreased pregnancy loss from 31 to $62 \mathrm{~d}$ of gestation (12.5 vs. 20.5\%). Despite a similar insemination rate, VitE cows had $22 \%$ greater pregnancy rate than control cows. Cows receiving vitamin E had decreased circulating cortisol and nonesterified fatty acids around calving. In summary, when cows were fed limited amounts of supplemental vitamin E, 28 to $48 \%$ of the recommendations, prepartum supplementation with injectable $\alpha$-tocopherol decreased incidence of RFM and improved reproduction.

Key words: dairy cow, reproduction, retained fetal membranes, vitamin $\mathrm{E}$

\section{INTRODUCTION}

Retained fetal membranes (RFM) is a common problem in dairy farms, and it can influence the risk of other diseases and fertility of dairy cows (Dubuc et al., 2010). The causes of RFM have not been completely elucidated; however, an important predisposing factor is the immune and antioxidant statuses before calving. For instance, during the transition period, dairy cows experience a reduction in immune function from approximately $14 \mathrm{~d}$ before to $21 \mathrm{~d}$ after calving, characterized by reduction in neutrophil and lymphocyte functions, especially on the day of calving (Goff and Horst, 1997). The reduction in neutrophil function has been linked to increased risk of RFM (Kimura et al., 2002).

It is well documented that immune function is depressed during the transition period in dairy cows, and the decreased neutrophil function is thought to increase the risk of infections, particularly mastitis (Hogan et al., 1992). During the normal metabolism of cells, reactive oxygen species (ROS) are generated and typically destroyed by cellular antioxidants that neutralize com- 
pounds with unpaired electrons to avoid cell membrane and DNA damage (Machlin and Bendich, 1987; Miller and Brzezinska-Slebodzinska, 1993). Vitamin E is a fat-soluble vitamin with antioxidant properties known for its effects on improving immune-cell function, such as function of PMNL. Supplementation with vitamin $\mathrm{E}$ increases incorporation of tocopherol into the cell membranes (Weiss et al., 1997), enhancing oxidative burst and killing activity against pathogens (Hogan et al., 1992). Improved neutrophil function has been postulated to be critical in the mechanisms involved in immune-cell detachment of the feto-maternal tissues (Gunnink, 1984a,b; Heuwieser and Grunert, 1987; Kimura et al., 2002), as evidenced by the link between decreased concentration of $\alpha$-tocopherol in blood and increased risk of RFM (Miller and Brzezinska-Slebodzinska, 1993; Weiss et al., 1997).

Around calving, concentrations of $\alpha$-tocopherol in blood decline (Weiss et al., 1992) because of transfer to colostrum (Goff et al., 2002), which is thought to increase the needs for vitamin E (Brzezinska-Slebodzinska et al., 1994) and the susceptibility to RFM (Miller and Brzezinska-Slebodzinska, 1993). In fact, the NRC (2001) suggests that dietary amounts of vitamin E should double during late gestation compared with the amounts during lactation. If dietary intake of vitamin $\mathrm{E}$ is inadequate, it might decrease $\alpha$-tocopherol concentrations in blood and increase the risk of RFM, which is known to affect uterine health and depress subsequent reproductive performance (Dubuc et al., 2010).

A second predisposing factor for RFM is circulating concentrations of cortisol during the week before calving. Indeed, researchers reported higher circulating cortisol in cows with RFM compared with cows without RFM (Peter and Bosu, 1987; Wischral et al., 2001). This suggests that stress near the time of calving, as indicated by an elevation in circulating cortisol, may increase the incidence of RFM. Thus, inadequate vitamin E supplementation and elevated cortisol around calving may be important risk factors that affect the incidence of RFM.

The main hypothesis of the current study was that cows fed limited amounts of dietary vitamin E would benefit from supplemental injectable $\alpha$-tocopherol during late gestation. A related hypothesis was that most prepartum cows on the farms studied have inadequate serum $\alpha$-tocopherol concentrations, which predisposes them to RFM and poor reproductive performance. A secondary hypothesis was that cows with RFM would exhibit elevations in circulating cortisol that would be diminished by supplemental $\alpha$-tocopherol. Therefore, the objectives were to evaluate the effect of supplemental injectable $\alpha$-tocopherol during the last 3 wk of gestation on the incidence of RFM and on productive and reproductive performance of dairy cows when fed limited amounts of vitamin $\mathrm{E}$ in the diet.

\section{MATERIALS AND METHODS}

All procedures with cows were approved by the ethics committee for animal use of the University of São Paulo, Escola Superior de Agricultura Luiz de Queiroz (protocol 2013-26).

\section{Cows and Farms}

A total of 890 dairy cows, 390 Holsteins (132 nulliparous and 258 parous) and 500 crossbred Holstein $\times$ Gyr (199 nulliparous and 301 parous), from 3 dairy farms in the southeastern region of Brazil were assigned to the study from May 2012 to April 2013. Farm 1 is a grazing system that milks approximately 600 crossbred cows that have access to pastures of Mombaça guinea grass (Panicum maximum Jacq. 'Mombaça') and are supplemented with corn silage, chopped sugar cane, and a grain mix containing ground corn, soybean meal, citrus pulp, whole cottonseed, and minerals and vitamins. Farm 2 is also a grazing system that milks approximately 610 crossbred cows that have access to pastures of Tifton 85 Bermuda grass (Cynodon spp.) and are supplemented with a mixture of corn silage and a grain mix containing finely ground corn, soybean meal, citrus pulp, whole cottonseed, and minerals and vitamins. Farm 3 is a confinement farm with freestall barns that milks approximately 550 Holstein cows that are fed a TMR containing corn silage, ryegrass silage, finely ground corn, soybean meal, whole cottonseed, and minerals and vitamins.

In all 3 farms, prepartum cows were housed in pastures with access to shade and water. From October to March, cattle had access to pasture and were managed as grazing cows supplemented with $2 \mathrm{~kg} / \mathrm{d}$ of a mixture of finely ground corn, soybean meal, and minerals and vitamins. From April to September, prepartum cattle received a TMR composed of corn silage, finely ground corn, soybean meal, and minerals and vitamins. During the prepartum period, cattle received 280 (farm 1), 390 (farm 2), and $480 \mathrm{IU}$ (farm 3) of supplemental vitamin E per day (DL- $\alpha$-tocopherol) and approximately 0.30 $\mathrm{mg} / \mathrm{kg}$ of Se in all 3 farms as part of the grain mix. The amount of minerals in the prepartum diet is described in Table 1. Dry matter intake of cows was expected to be around $10 \mathrm{~kg} / \mathrm{d}$ provided by pasture during summer and supplementation with grain mix to reach the requirements of prepartum cows. In all farms, cows were milked 3 times daily and fed concentrate concurrent with milking, whereas prepartum, concentrate was fed once daily. 
Table 1. Composition of minerals in the prepartum diet (formulated values)

\begin{tabular}{lrrc}
\hline Element & Farm 1 & Farm 2 & Farm 3 \\
\hline DMI, kg & 11.80 & 10.90 & 11.30 \\
Ca, \% of DM & 1.00 & 0.91 & 0.81 \\
P, \% of DM & 0.28 & 0.49 & 0.30 \\
$\mathrm{Mg}, \%$ of DM & 0.29 & 0.48 & 0.42 \\
$\mathrm{Na}, \%$ of DM & 0.05 & 0.05 & 0.09 \\
$\mathrm{Fe}, \mathrm{mg} / \mathrm{kg}$ & 190.00 & 87.00 & 221.00 \\
$\mathrm{Zn}, \mathrm{mg} / \mathrm{kg}$ & 67.00 & 81.00 & 85.00 \\
$\mathrm{Co}, \mathrm{mg} / \mathrm{kg}$ & 0.29 & 0.45 & 0.45 \\
$\mathrm{I}, \mathrm{mg} / \mathrm{kg}$ & 0.51 & 1.00 & 0.47 \\
$\mathrm{Mn}, \mathrm{mg} / \mathrm{kg}$ & 61.00 & 86.00 & 76 \\
$\mathrm{Se}, \mathrm{mg} / \mathrm{kg}$ & 0.29 & 0.38 & 0.37 \\
$\mathrm{Cu}, \mathrm{mg} / \mathrm{kg}$ & 17.00 & 18.00 & 18.5 \\
Vitamin A, kIU & 33.00 & 62.00 & 79.00 \\
Vitamin D, kIU & 7.500 & 15.00 & 19.00 \\
Vitamin E, IU & 280.00 & 390.00 & 480.00 \\
\hline
\end{tabular}

\section{Experimental Design and Treatments}

The study was conducted as a completely randomized design. Within farm, weekly cohorts of cows at approximately $258 \pm 3 \mathrm{~d}$ of gestation were randomly assigned to remain as untreated controls or to receive $3 \mathrm{i} . \mathrm{m}$. injections of 1,000 IU each of DL- $\alpha$-tocopherol (Monovim $\mathrm{E}$, Bravet, Brazil) administered at $19.2 \pm 4.3,12.9 \pm$ 3.3 , and $6.2 \pm 2.9 \mathrm{~d}$ in relation to calving date (VitE). This dose has been reported to increase $\alpha$-tocopherol in serum for approximately $2 \mathrm{wk}$ (Erskine et al., 1997). Within farm, treatment was administered by the same person throughout the study period. Cows that calved with fewer than 7 or more than $28 \mathrm{~d}$ in relation to the day of randomization were excluded from the study. So, cows were allocated to remain as untreated (control) or to the supplemented group (VitE) between 7 and $28 \mathrm{~d}$ in relation to the actual date of calving.

\section{Diagnosis of RFM and Stillbirth}

In all 3 farms, prepartum cows were observed for signs of calving from approximately 0600 to $1800 \mathrm{~h}$. The approximate time of calving was recorded for each cow during the observation period. Every morning, cows that calved until $1800 \mathrm{~h}$ of the previous day were observed for presence of fetal membranes, and those in which membranes were present were considered to have RFM. Cows that calved from $1800 \mathrm{~h}$ until the next morning were only evaluated for presence of fetal membranes on the following morning. Therefore, cows considered to have RFM had the placenta present for at least $12 \mathrm{~h}$ after parturition. Cows with gestation of at least $255 \mathrm{~d}$ that resulted in calves born dead or those that died within the first hours after birth were considered stillbirth.
All cows with RFM received therapy with $10 \mathrm{mg} / \mathrm{kg}$ of BW of oxytetracycline via intravenous injection (Reverin Plus, MSD Saúde Animal, São Paulo, Brazil) plus $500 \mathrm{~mL}$ of propylene glycol diluted in $50 \mathrm{~L}$ of rehydrating oral solution containing water, $\mathrm{NaCl}, \mathrm{CaCl}_{2}$, and $\mathrm{MgSO}_{4}$. Cows received therapy for 3 to 5 consecutive days, starting immediately after diagnosis of RFM, at least $12 \mathrm{~h}$ after calving, according to clinical assessment by the herd personnel.

\section{Reproductive Management for First AI}

Each farm had a specific reproductive-management program. In farm 1, the voluntary waiting period was $40 \mathrm{~d}$. Cows were observed for signs of estrus based on multiple visual observation periods during the day. Cows observed in standing estrus were inseminated 12 $\mathrm{h}$ later, such that cows observed in the morning were inseminated late afternoon and those observed in estrus in the afternoon were inseminated the following morning. Every other week, cows not observed in estrus after 60 DIM had ovulation synchronized for timed AI using $2 \mathrm{mg}$ of estradiol benzoate $(1 \mathrm{mg} / \mathrm{mL}$ of estradiol benzoate; Gonadiol, MSD Saúde Animal) and a controlled internal drug-release insert (CIDR) containing $1.9 \mathrm{~g}$ of progesterone (CIDR, Zoetis, São Paulo, Brazil) on d 0 of the protocol. Seven days later, cows received $0.5 \mathrm{mg}$ of cloprostenol $(0.25 \mathrm{mg} / \mathrm{mL}$ of cloprostenol; Sincrocio, Ourofino Agronegócio, Cravinhos, Brazil). On $\mathrm{d}$ 8.5, the CIDR was removed and cows received another dose of $0.5 \mathrm{mg}$ of cloprostenol and $1 \mathrm{mg}$ of estradiol benzoate. Cows were time inseminated on $\mathrm{d}$ 10. In farm 2, the voluntary waiting period was $45 \mathrm{~d}$. Cows were observed for signs of estrus based on visual observation during the day. Cows observed in standing estrus were inseminated $12 \mathrm{~h}$ later, as described for farm 1. Every other week, cows not observed in estrus past 55 DIM had ovulation synchronized for timed AI using $2 \mathrm{mg}$ of estradiol benzoate and a CIDR on d 0 of the protocol. Eight days later, cows received $0.5 \mathrm{mg}$ of cloprostenol, the CIDR was removed, and they received $1 \mathrm{mg}$ of estradiol cypionate $(2 \mathrm{mg} / \mathrm{mL}$ of estradiol cypionate; ECP, Zoetis). Cows were time inseminated on d 10 of the protocol. Two technicians inseminated all cows throughout the study.

In farm 3, the voluntary waiting period was $60 \mathrm{~d}$. Cows received $0.5 \mathrm{mg}$ of cloprostenol at $46 \pm 3$ and again at $60 \pm 3$ DIM. Cows observed in estrus after the second treatment with cloprostenol were inseminated following the am-pm rule as described above for farms 1 and 2. Cows not observed in estrus within $14 \mathrm{~d}$ of the second cloprostenol treatment had their ovaries evaluated using an ultrasound (Mindray 2200, 
Mindray, Huntingdon, United Kingdom) equipped with a transrectal 7.5-MHz linear probe; cows with a corpus luteum (CL) received another dose of cloprostenol and were further observed for estrus. Cows without a CL had ovulation synchronized with $100 \mu \mathrm{g}$ of $\mathrm{GnRH}(100$ $\mu \mathrm{g} / \mathrm{mL}$ of gonadorelin; Fertagyl, MSD Saúde Animal) on $\mathrm{d} 0$. Seven days later cows received $0.5 \mathrm{mg}$ of cloprostenol. On d 8, cows received $1 \mathrm{mg}$ of estradiol cypionate and were time inseminated on d 9.5 concurrent with a dose of GnRH. Two technicians per herd inseminated all cows throughout the study.

\section{Pregnancy Diagnosis and Resynchronization of Nonpregnant Cows}

Inseminated cows were observed for visual signs of estrus throughout the study and, if observed in estrus, were inseminated following the am-pm rule as described previously. On farms 1 and 3, pregnancy diagnosis was performed weekly, whereas on farm 2 it was performed every other week. In all 3 farms, cows that were at least $28 \mathrm{~d}$ after the last insemination were eligible for pregnancy diagnosis using ultrasonography. Cows with an embryonic vesicle were considered pregnant. In farms 1 and 3, the diagnosis of pregnancy averaged $31 \mathrm{~d}$ after AI. Cows in farm 2 averaged $35 \mathrm{~d}$ after AI. For consistency, throughout the manuscript the first pregnancy diagnosis will be called pregnancy on d 31. All pregnant cows were reconfirmed at $62 \pm 3 \mathrm{~d}$ after $\mathrm{AI}$ on all 3 farms by transrectal palpation of the uterus.

In farms 1 and 3, nonpregnant cows had their estrous cycle resynchronized according to the respective hormonal protocols described for first AI. In farm 2, nonpregnant cows with a CL received cloprostenol and were observed for estrus. Those without a CL had the estrous cycle resynchronized using the same protocol for first AI.

Reproductive performance was evaluated up to 200 DIM in all 3 farms. Inseminations performed up to 200 DIM were used in the analysis, until the cow was confirmed pregnant at d 62 of gestation. A cow was considered pregnant at the end of the study based on the diagnosis performed on $\mathrm{d} 62 \pm 3$ after insemination. Considering the voluntary waiting period of farm 1 of 40 DIM, farm 2 of 45 DIM, and that of farm 3 of 60 DIM, and the average length of the estrous cycle of 21 $\mathrm{d}$, each cow was expected to have a maximum of 7.6, 7.3, and 6.6 twenty-one-day estrous cycles during the study. Cows that were sold, died, or designated "do not inseminate" were censored on the respective day. Cows that remained in the study but were not pregnant by 200 DIM were censored on d 200.

For the 21-d-cycle insemination rate and pregnancy rate, cows became eligible starting at the voluntary waiting period for the respective farm until the day of AI that resulted in pregnancy or until censored.

\section{Milk Yield}

Milk yield was recorded every $14 \mathrm{~d}$ on farms 1 and 2, and daily on farm 3. On farms 1 and 2, production was measured using manual milk meters (MM6, DeLaval, Campinas, Brazil), whereas on farm 3, production was measured using electronic milk meters (Meatron MB milk meter, GEA Farm Technologies do Brasil, Jaguariúna, Brazil). Production was averaged for the first 60 , 100 , and $305 \mathrm{~d}$ of lactation. Cows that were sold or died before 60,100 , or 305 DIM contributed with measurements up to the day they left the study.

\section{Blood Sampling and Analyses}

All blood samplings were performed at $0800 \mathrm{~h}$, approximately $1 \mathrm{~h}$ before feeding. Blood was sampled from a subset of randomly selected cows from each farm before treatments were initiated to establish the baseline concentration of $\alpha$-tocopherol in serum and to determine the prevalence of cows with inadequate concentrations prepartum based on the threshold of 3.0 $\mu \mathrm{g} / \mathrm{mL}$ (Weiss et al., 1997). A total of 141 cows (32 controls and 32 VitE from farm 1; 16 controls and 18 VitE from farm 2; and 27 controls and 16 VitE from farm 3) had blood sampled by puncture of the coccygeal blood vessels using evacuated tubes with no anticlotting agent and with serum separator (Vacuplast Collect Line, Nanchang, China). Samples were allowed to clot at room temperature and were then placed in a refrigerator within $30 \mathrm{~min}$. Tubes were centrifuged within $6 \mathrm{~h}$ of collection, and serum was harvested and frozen at $-20^{\circ} \mathrm{C}$ until analysis. Sera were assayed for concentrations of $\alpha$-tocopherol by HPLC, as described by Arnaud et al. (1991), in an analytical laboratory (Nanocore Biotecnologia SA, Campinas, Brazil). A single assay was performed, and the CV was $2.9 \%$. Serum cholesterol concentrations were analyzed by an end-point colorimetric assay (Cholesterol Liquiform, Labtest, Lagoa Santa, Brazil) with an intraassay CV of $7.8 \%$.

Blood was also sampled by puncture of the coccygeal blood vessels and processed as described above from a subset of randomly selected cows on each farm (36 controls and 28 VitE in farm 1; 34 controls and 34 VitE in farm 2; and 15 controls and $25 \mathrm{VitE}$ in farm 3 ). Cows were sampled once weekly starting 3 wk prepartum to 3 wk postpartum. Concentrations of NEFA in serum were measured using a commercial kit (NEFA FA 115 Kit, Randox Inc., Crumlin, UK; Johnson and Peters, 1993) in all pre- and postpartum samples. The intra- and 
interassay CV were 2.5 and $6.0 \%$. Concentrations of cortisol in serum were measured on the last 2 samples collected prepartum by RIA using a commercial kit (DiaSorin Inc., Dartford, UK). A single assay was performed, and the intraassay CV was $1.4 \%$.

\section{Statistical Analyses}

Records from the study farms were evaluated to determine the baseline incidence of RFM. In the 12 mo preceding the beginning of the study, $18 \%$ of the cows were diagnosed with RFM. Previous studies indicated that injectable vitamin $\mathrm{E}$ decreased RFM by 6 percentage units (Erskine et al., 1997). Therefore, a sample size was calculated $(\alpha=0.05 ; \beta=0.10)$ to provide sufficient experimental units to detect a reduction in RFM from 18 to $12 \%$. A total of 760 cows (380 per treatment) were considered the minimum necessary for the study. Additional cows were included because of potential attrition and errors with date of calving that would limit the number of treatments with VitE, and to provide additional power to detect differences in reproductive performance such as pregnancies per AI $(\mathbf{P} / \mathbf{A I})$ and pregnancy rate.

Binary variables were analyzed by logistic regression using the GLIMMIX procedure of SAS (SAS STAT ver. 9.3, Cary, NC) fitting a binary distribution with a logit error distribution. All models included the effects of treatment (control vs. VitE), parity (nulliparous vs. parous), and farm (1 vs. 2 vs. 3 ). The interactions between treatment and parity and treatment and farm were included when $P<0.10$. For $\mathrm{P} / \mathrm{AI}$ and pregnancy loss, sire within farm and technician within farm were also included if $P<0.10$. The adjusted odds ratios (AOR) and respective 95\% CI were calculated.

The intervals from calving to first insemination and calving to pregnancy were analyzed by the Cox's proportional hazard model using the PHREG procedure of SAS with models that included the effects of treatment, parity, farm, interaction between treatment and parity, and interaction between treatment and farm. Interactions with $P>0.10$ were removed from the final models. Cows coded as do not inseminate before the end of the voluntary waiting period of each farm were excluded from the analyses. Nonpregnant cows that left the study because of culling or death before 200 DIM were censored on the respective day. Cows that remained open by 200 DIM were also censored. The adjusted hazard ratios (AHR) and respective 95\% CI were calculated for time-dependent categorical data. Proportionality of the hazards was assessed, and the Kaplan-Meier curves were generated using the LIFETEST procedure of SAS. Median and mean days to pregnancy were generated by the Kaplan-Meyer method using the LIFETEST procedure of SAS.

Continuous variables were tested for normality of the residuals. When residuals were not normally distributed, then data were transformed by logarithm before analysis. Concentrations of NEFA, cortisol, $\alpha$-tocopherol, and the ratio of $\alpha$-tocopherol:cholesterol in serum, and milk yield were analyzed by ANOVA with the MIXED procedure of SAS. For responses with repeated measures within cow, the models included the fixed effects of treatment; parity; farm; week of measurement; and the interactions between treatment and week, treatment and parity, and treatment and farm, and the random effect of cow nested within treatment. For responses with a single value per cow, such as milk yield and $\alpha$-tocopherol, the models included the fixed effects of treatment, parity, farm, and the interactions between treatment and parity, and treatment and farm.

Additional analyses were performed to determine whether concentration of $\alpha$-tocopherol 3 wk prepartum was a predictor of RFM postpartum. Finally, analyses were performed including RFM in the statistical models to determine any association between RFM and reproductive performance of dairy cows.

Data are presented as LSM $\pm \mathrm{SE}$, unless otherwise stated. Differences with $P \leq 0.05$ were considered statistically significant, and those with $0.05<P \leq 0.10$ were considered as a tendency.

\section{RESULTS}

\section{Serum $\alpha$-Tocopherol and $\alpha$-Tocopherol:Cholesterol Ratio Prepartum}

The concentration of $\alpha$-tocopherol in serum at 3 wk prepartum was similar $(P=0.87)$ between control and VitE and averaged $2.97 \pm 0.10 \mu \mathrm{g} / \mathrm{mL}$. Similarly, $\alpha$-tocopherol:cholesterol ratio did not differ $(P=0.82)$ between treatments and averaged $4.46 \pm 0.16 \times 10^{-3}$. Parous cows had a greater concentration $(P=0.02)$ of tocopherol than nulliparous cows $(3.15 \pm 0.11$ vs. $2.80 \pm 0.10 \mu \mathrm{g} / \mathrm{mL}$ ). Farm of origin did not influence the concentrations of serum $\alpha$-tocopherol. In total, $53.2 \%$ of the cows had inadequate concentration of $\alpha$-tocopherol in serum when based on the $3.0 \mu \mathrm{g} / \mathrm{mL}$ cut-off for adequacy as suggested by Weiss et al. (1997). The proportion of cows with low $\alpha$-tocopherol did not differ for control $(52.0 \%)$ or VitE $(54.6 \%)$ on the day of study enrollment. For cows that had not yet been treated, as day of calving approached, the concentration of $\alpha$-tocopherol in serum declined $(P=0.005)$, approximately $0.07 \mu \mathrm{g} / \mathrm{mL}$ for each day closer to calving (Figure 1A). 


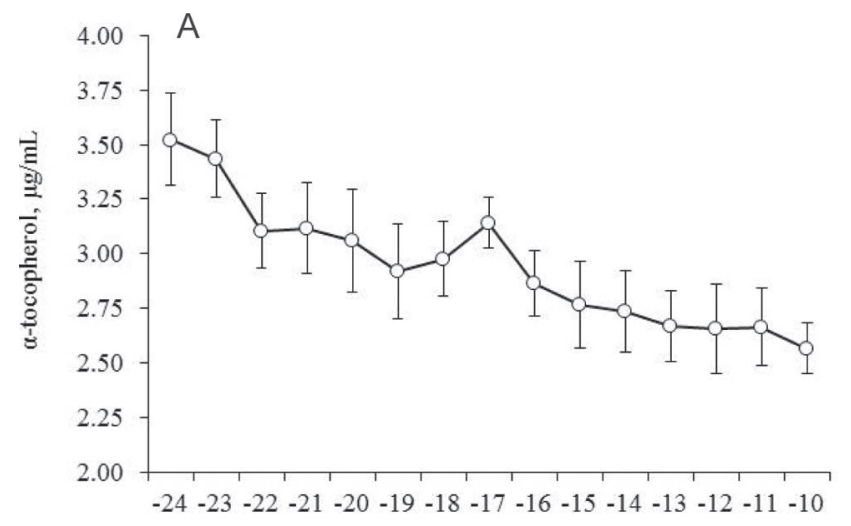

Day relative to calving

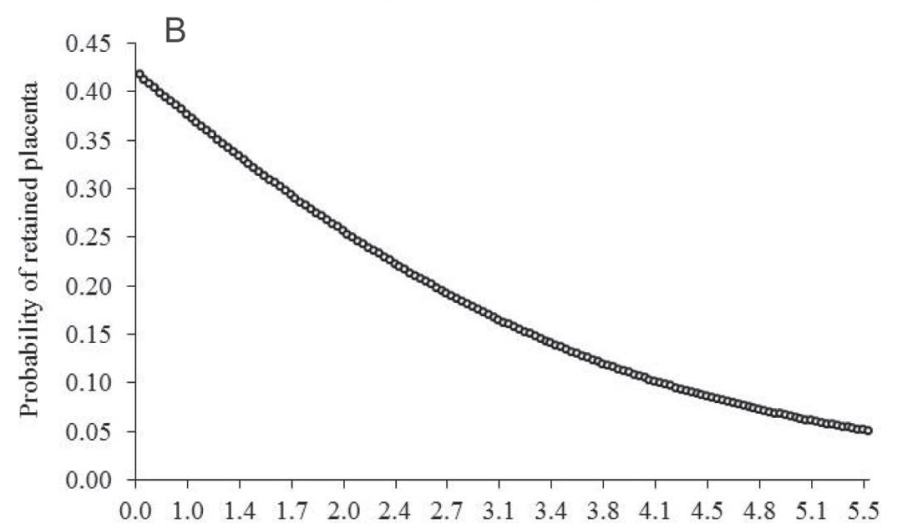

Serum $\alpha$-tocopherol 3 wk prepartum, $\mu \mathrm{g} / \mathrm{mL}$

Figure 1. Concentration of $\alpha$-tocopherol (means and SD) in serum according to day relative to calving when cows were enrolled in the study (A) and probability of retained fetal membranes according to concentration of $\alpha$-tocopherol in serum at study enrollment $(258 \pm 3$ $\mathrm{d}$ of gestation). For panel A, concentration of $\alpha$-tocopherol decreased $(P=0.005)$ as parturition approached. The number of samples in each time point, from 24 to $10 \mathrm{~d}$ prepartum, were 1 ( $24 \mathrm{~d}), 1$ ( $23 \mathrm{~d}), 8$ (22 d), 19 (21 d), 18 (20 d), 21 (19 d), 17 (18 d), 9 (17 d), 6 (16 d), 11 (15 d), $13(14 \mathrm{~d}), 6(13 \mathrm{~d}), 5(12 \mathrm{~d}), 3(11 \mathrm{~d})$, and $3(10 \mathrm{~d})$. For panel B, every $1-\mu \mathrm{g} / \mathrm{mL}$ increase in serum $\alpha$-tocopherol decreased $(P=0.01)$ the odds of having retained placenta by $48 \%$ (adjusted odds ratio $=$ $0.52 ; 95 \% \mathrm{CI}=0.30-0.89)$.
The probability of cows to have RFM decreased ( $P$ $=0.01)$ as the prepartum concentration of $\alpha$-tocopherol in serum increased (Figure 1B). For each additional 1 $\mu \mathrm{g} / \mathrm{mL}$ in serum $\alpha$-tocopherol, the odds of having RFM decreased by $48 \%(\mathrm{AOR}=0.52 ; 95 \% \mathrm{CI}=0.30$ to $0.89)$. When all cows were analyzed, those having a low $(<3.0 \mu \mathrm{g} / \mathrm{mL})$ concentration of $\alpha$-tocopherol in serum had a 2.8 -fold increase $(P=0.04)$ in odds $(95 \% \mathrm{CI}=$ 1.03 to 7.52 ) of having RFM after calving compared with cows considered to have an adequate $(\geq 3.0 \mu \mathrm{g} /$ $\mathrm{mL}$ ) concentration of $\alpha$-tocopherol in serum (22.7 vs. $13.6 \%)$.

\section{Postpartum Health and Lactation Performance}

The incidence of RFM decreased $(P=0.007)$ in VitE compared with control cows (Table 2). Similarly, the incidence of stillbirths was decreased $(P<0.001)$ to less than half of that of controls when cows were supplemented with VitE prepartum. The odds of a cow to die in the first 200 DIM tended $(P=0.07)$ to increase 2.28 -fold in controls compared with VitE cows. Despite differences in postpartum health, supplemental injectable $\alpha$-tocopherol prepartum did not influence yield of milk measured in the first 60, 100, or 305 DIM (Table $2)$.

\section{Serum Concentrations of Cortisol and NEFA}

Concentrations of cortisol in serum did not differ between treatments at $2 \mathrm{wk}$ before calving (Figure $2 \mathrm{~A}$ ). The concentration of cortisol in serum increased $(P=$ $0.05)$ in cows in the control group in the week preceding calving but not in cows receiving VitE. Because of that, concentrations of cortisol were greater $(P=0.05)$ for control than VitE in the week before calving. Moreover, the probability of cows to have RFM increased $(P=0.05)$ as the concentration of cortisol in serum in the week before calving increased. For each 1-ng/

Table 2. Effect of injectable vitamin E prepartum on health of dairy cows and production

\begin{tabular}{lcccc}
\hline & \multicolumn{2}{c}{ Treatment $^{1}$} & & \\
\cline { 2 - 3 } Item & Control & VitE & $(95 \%$ CI $)$ & $P$-value \\
\hline Cows, no. & 441 & 449 & - & - \\
Retained fetal membranes, \% & 20.1 & 13.5 & $1.68(1.15-2.44)$ & 0.007 \\
Stillbirth, \% & 14.9 & 6.8 & $2.42(1.44-4.07)$ & 0.001 \\
Death by 200 DIM, \% & 5.4 & 2.4 & $2.28(0.92-5.65)$ & 0.07 \\
Milk yield, kg ( \pm SE) & & & & 0.96 \\
60 DIM & $1,398 \pm 28$ & $1,400 \pm 28$ & - & 0.46 \\
100 DIM & $2,425 \pm 47$ & $2,388 \pm 46$ & - & 0.59 \\
305 DIM & $6,478 \pm 109$ & $6,413 \pm 108$ & - & \\
\hline
\end{tabular}

${ }^{1}$ Cows were randomly assigned to receive no injectable vitamin E (control) or 3 injections prepartum of 1,000 IU of vitamin $\mathrm{E}$ each at $258 \pm 3,265 \pm 3$, and $272 \pm 3 \mathrm{~d}$ of gestation (VitE).

${ }^{2} \mathrm{AOR}=$ adjusted odds ratio. Vitamin $\mathrm{E}$ is the reference for comparison. 
$\mathrm{mL}$ increase in serum cortisol, the odds of having RFM increased by $4 \%(\mathrm{AOR}=1.04 ; 95 \% \mathrm{CI}=1.00$ to 1.09$)$.

Cows receiving supplemental injectable $\alpha$-tocopherol tended $(P=0.10)$ to have a decreased concentration of NEFA in serum compared with controls in the week before calving (Figure 2B). After calving, the concentration of NEFA was less $(P=0.05)$ for VitE than controls $(0.63 \pm 0.04$ vs. $0.53 \pm 0.04 \mathrm{mM})$, and this difference was observed primarily in the week of calving. Cows with RFM had greater $(P=0.01)$ circulating NEFA at 3 wk prepartum than cows without RFM $(0.44 \pm$ 0.05 vs. $0.30 \pm 0.04 \mathrm{~m} M)$; also, a tendency $(P=0.06)$ of increased circulating NEFA on wk 1 before calving was observed for cows with RFM compared with those without RFM $(0.53 \pm 0.03$ vs. $0.44 \pm 0.03 \mathrm{mM})$. No difference in serum NEFA at 2 wk prepartum was observed between cows with or without RFM.

\section{Reproductive Performance}

Of the 890 cows that initiated the study, $81.4 \%$ received at least one AI in the first 200 DIM (control = $82.8 \%$; VitE $=80.0 \%$ ), and $18.6 \%$ were designated as "do not inseminate" or were sold or died before any AI. The interval postpartum to first AI did not differ $(P=0.12)$ between control and VitE cows (Table 3$)$, because the rate of insemination was not affected $(P=$ $0.28)$ by prepartum treatments $(\mathrm{AHR}=1.08 ; 95 \% \mathrm{CI}$ $=0.94$ to 1.25 ). No interaction was observed between treatment and parity or treatment and farm for interval to first AI.

The $\mathrm{P} / \mathrm{AI}$ at first $\mathrm{AI}$ did not differ $(P=0.30)$ between treatments on d 31 after insemination (Table 3 ); however, because of decreased $(P=0.01)$ pregnancy loss for VitE cows, they tended $(P=0.08)$ to have a 6.6 percentage units greater $\mathrm{P} / \mathrm{AI}$ when pregnancy was evaluated on d 62 after the first insemination postpartum. A total of 1,591 inseminations were performed in the first 200 DIM, 837 in control cows and 754 in VitE cows. The $\mathrm{P} / \mathrm{AI}$ for all inseminations was greater for VitE than control when pregnancy diagnoses were performed either on d $31(P=0.02)$ or $62(P=0.01)$ after inseminations. As for first AI, the risk of pregnancy loss between 31 and $62 \mathrm{~d}$ of gestation was greater $(P=$ 0.03 ) for control than VitE cows (Table 3). Pregnancies per AI at first and all AI were influenced by farm and by parity, but no interactions between treatment and parity or treatment and farm were observed. On $62 \mathrm{~d}$ after all $\mathrm{AI}, \mathrm{P} / \mathrm{AI}$ was greater $(P=0.04)$ for primiparous than multiparous cows (33.4 vs. $27.6 \%$ ).

The rate of insemination calculated at 21 -d intervals was similar $(P=0.63)$ between treatments and averaged $50.0 \%$ (Table 3 ). Nevertheless, the 21-d-cycle pregnancy rate tended $(P=0.08)$ to be greater for VitE

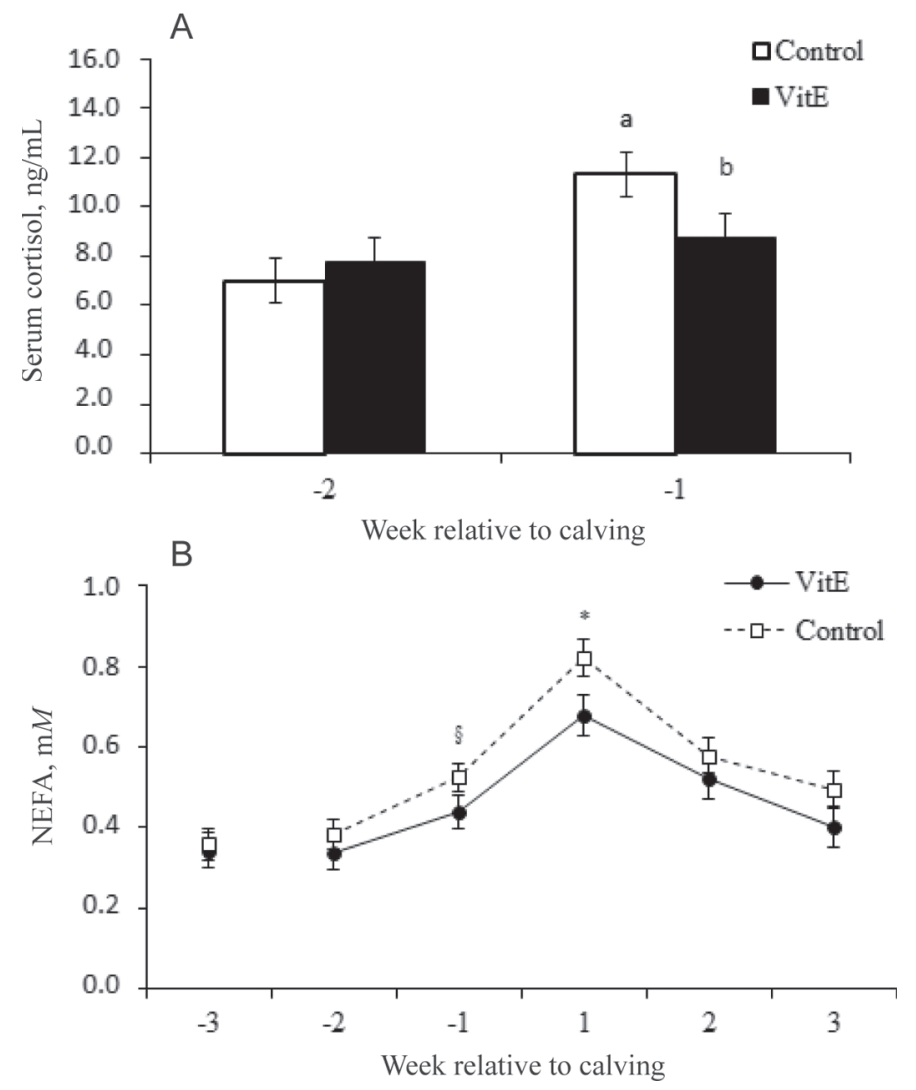

Figure 2. Mean $( \pm \mathrm{SE})$ concentrations of cortisol prepartum (A) and of NEFA (B) in serum of cows receiving no injectable vitamin E (control, $\mathrm{n}=85$ ) or 3 injections of 1,000 IU of vitamin $\mathrm{E}$ each at 19.2 $\pm 4.3,12.9 \pm 3.3$, and $6.2 \pm 2.9 \mathrm{~d}$ before calving (VitE, $\mathrm{n}=87$ ). For serum cortisol, different superscripts within a day denote effect of treatment $\left({ }^{\mathrm{a}, \mathrm{b}} P<0.05\right)$. For serum NEFA, ${ }^{*}$ denotes effect of treatment $(P<0.05)$, and $\S$ denotes tendency for effect of treatment $(P$ $<0.10)$.

than control cows. In fact, when time to pregnancy was analyzed by the Cox's proportional hazard model, cows that received VitE became pregnant faster $(P=0.03)$ than control cows $(\mathrm{AHR}=1.22 ; 95 \% \mathrm{CI}=1.02$ to 1.46), resulting in a reduction of $11 \mathrm{~d}$ in median time to pregnancy (Figure 3). At 200 DIM, 52.4 and 57.3 of the control and VitE cows were pregnant. Both farm and parity influenced the rate of pregnancy, but no interactions with treatment were observed. Primiparous cows became pregnant faster $(P \leq 0.01)$ than multiparous cows $(\mathrm{AHR}=1.31 ; 95 \% \mathrm{CI}=1.09$ to 1.58$)$.

Cows without RFM tended to became pregnant faster $(P=0.09)$ than RFM cows $(\mathrm{AHR}=1.24 ; 95 \% \mathrm{CI}=$ 0.96 to 1.60$)$, resulting in a reduction in median days open of $27 \mathrm{~d}$ (Figure 4). Although RFM did not affect $(P=0.66) \mathrm{P} / \mathrm{AI}$ evaluated on d 31 after insemination, pregnancy loss between 31 and $62 \mathrm{~d}$ of gestation tended $(P=0.09)$ to be greater for cows with RFM than for cows without RFM (25.0 vs. 16.4\%). Also, an inter- 


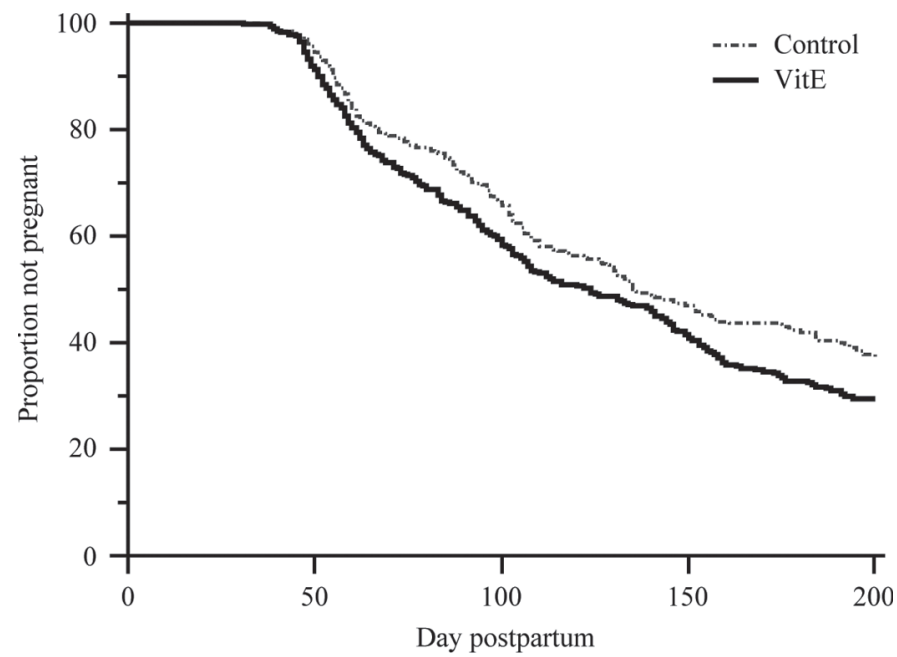

Figure 3. Survival curves for interval to pregnancy in cows receiving no injectable vitamin $\mathrm{E}$ (control, $\mathrm{n}=433$ ) or 3 injections of 1,000 IU of vitamin $\mathrm{E}$ each at $258 \pm 3,265 \pm 3$, and $272 \pm 3 \mathrm{~d}$ of gestation (VitE, $\mathrm{n}=433)$. Cows receiving VitE became pregnant faster $(P=$ 0.03 ) than control cows (adjusted hazard ratio $=1.22 ; 95 \% \mathrm{CI}=$ $1.02-1.46)$. At $200 \mathrm{~d}$ postpartum, 52.4 and $57.3 \%$ of the control and VitE cows were pregnant ( 47.6 and $42.7 \%$ were censored, respectively). The median and mean $( \pm \mathrm{SE})$ days open were, respectively, 135 and $137.4 \pm 3.1$ for control and 124 and $125.9 \pm 3.0$ for VitE.

action $(P=0.04)$ between treatment and RFM was observed for the 21-d-cycle pregnancy rate because in control cows, RFM decreased pregnancy rate from 17.9 to $13.1 \%$, whereas for cows receiving VitE the pregnan- cy rate was similar between those not diagnosed with RFM (19.1\%) and those diagnosed with RFM (20.4\%).

\section{DISCUSSION}

The vitamin E status of cows during the last few weeks of gestation can have important effects on postpartum health and performance; however, many producers around the world continue to supplement dry cows with insufficient vitamin E. Prepartum cows in the current study received less than $50 \%$ of the dietary recommendation of 1,000 IU of supplemental vitamin $\mathrm{E}$ suggested by the NRC (2001) for late-gestation dairy cows that are not grazing. It is anticipated that $10 \mathrm{~kg}$ of DMI from pasture would provide approximately 235 IU of vitamin E to prepartum cows, based on $23.5 \mathrm{mg} / \mathrm{kg}$ reported by Arizmendi et al. (2005) for Tifton-85. The same study reported little variation between 4 tropical forages during seasons with normal or extended days, ranging from 23 to $35 \mathrm{mg} / \mathrm{kg}$. This amount of vitamin E is still expected to be insufficient for prepartum dairy cows, as evidenced by the observation that $53 \%$ of the cows in this study had marginal concentrations of serum $\alpha$-tocopherol at study enrollment.

Low concentrations of $\alpha$-tocopherol in blood have been shown to increase the risk of peripartum diseases, namely mastitis and RFM (Miller and BrzezinskaSlebodzinska, 1993; Weiss et al., 1997; LeBlanc et al., 2004). Therefore, we anticipated that supplementing

Table 3. Effect of injectable vitamin E prepartum on reproductive performance of dairy cows

\begin{tabular}{|c|c|c|c|c|}
\hline \multirow[b]{2}{*}{ Item } & \multicolumn{2}{|c|}{ Treatment $^{1}$} & \multirow{2}{*}{$\begin{array}{c}\mathrm{AOR}^{2} \\
(95 \% \mathrm{CI})\end{array}$} & \multirow[b]{2}{*}{$P$-value } \\
\hline & Control & VitE & & \\
\hline Cows, ${ }^{3}$ no. & 362 & 344 & - & - \\
\hline Days postpartum at first $\mathrm{AI}( \pm \mathrm{SE})$ & $64.3 \pm 1.2$ & $62.1 \pm 1.3$ & - & 0.12 \\
\hline \multicolumn{5}{|l|}{ First postpartum AI } \\
\hline Pregnant d 31, \% & 38.1 & 42.1 & $0.85(0.63-1.16)$ & 0.30 \\
\hline Pregnant d $62, \%$ & 30.1 & 36.7 & $0.76(0.55-1.04)$ & 0.08 \\
\hline Pregnancy loss, $\%$ & 20.5 & 12.5 & $2.30(1.14-4.63)$ & 0.01 \\
\hline \multicolumn{5}{|l|}{ All inseminations up to $200 \mathrm{DIM}$} \\
\hline Pregnant d $31, \%$ & 34.5 & 38.4 & $0.59(0.37-0.95)$ & 0.02 \\
\hline Pregnant d $62, \%$ & 26.9 & 32.8 & $0.54(0.33-0.88)$ & 0.01 \\
\hline Pregnancy loss, $\%$ & 21.1 & 14.5 & $1.59(1.02-2.47)$ & 0.03 \\
\hline Cows, ${ }^{4}$ no. & 397 & 396 & & \\
\hline 21 -d-cycle insemination rate, ${ }^{5} \%$ & 49.2 & 50.8 & $0.97(0.84-1.11)$ & 0.63 \\
\hline 21-d-cycle pregnancy rate, ${ }^{6} \%$ & 16.7 & 19.3 & $0.85(0.70-1.03)$ & 0.08 \\
\hline
\end{tabular}

${ }^{1}$ Cows were randomly assigned to receive no injectable vitamin $\mathrm{E}$ (control) or 3 injections prepartum of 1,000 IU of vitamin E each at $258 \pm 3,265 \pm 3$, and $272 \pm 3 \mathrm{~d}$ of gestation (VitE).

${ }^{2} \mathrm{AOR}=$ adjusted odds ratio. Vitamin $\mathrm{E}$ is the reference for comparison.

${ }^{3}$ Includes only cows that received at least one insemination in the first $200 \mathrm{~d}$ postpartum and were either reinseminated and considered nonpregnant or had pregnancy diagnosis performed after first AI.

${ }^{4}$ Number of cows with at least one 21-d cycle after voluntary waiting period in the trial.

${ }^{5}$ Calculated as the proportion of cows inseminated each 21-d period past the end of the voluntary waiting period out of all eligible cows to become pregnant.

${ }^{6}$ Calculated as the proportion of cows pregnant each 21-d period past the end of the voluntary waiting period out of all eligible cows to become pregnant. 


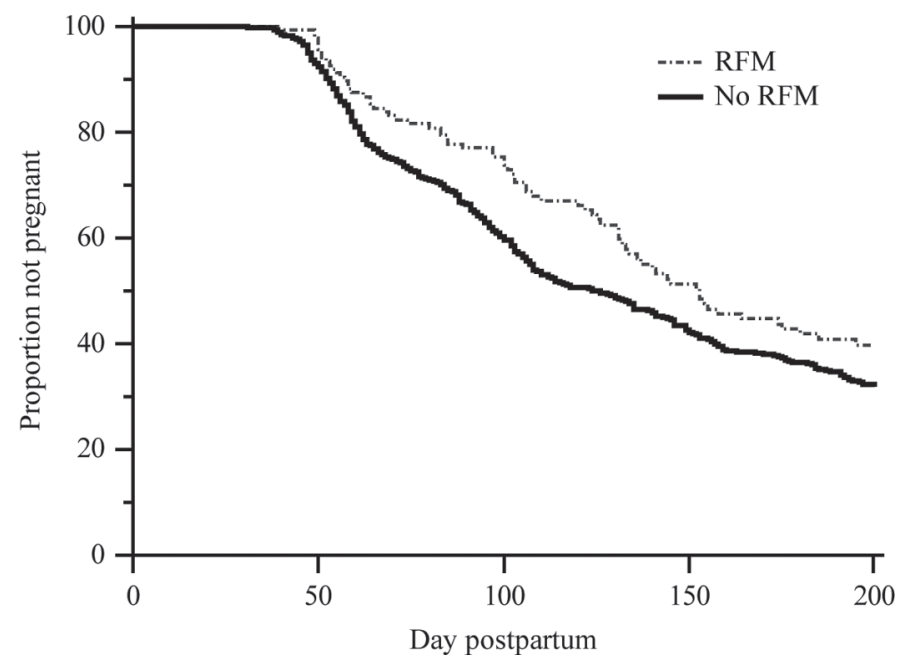

Figure 4. Survival curves for interval to pregnancy in cows not diagnosed with retained fetal membranes (no RFM; $\mathrm{n}=714$ ) and in cows diagnosed with RFM ( $\mathrm{n}=152)$. Cows not diagnosed with RFM tended $(P=0.09)$ to become pregnant faster than those diagnosed with RFM (adjusted hazard ratio $=1.24 ; 95 \% \mathrm{CI}=0.96-1.60$ ). At 200 d postpartum, 56.4 and $47.4 \%$ of the cows with no RFM and cows with RFM were pregnant (43.6 and $52.6 \%$ were censored, respectively). The median and mean $( \pm \mathrm{SE}$ ) days open were, respectively, 126 and 130.2 \pm 2.4 for cows without RFM and 153 and $142.3 \pm 4.8$ for cows with RFM.

cows with injectable vitamin $\mathrm{E}$ during the last 3 wk of gestation would decrease the risk of RFM and improve reproductive performance. In fact, administration of $1,000 \mathrm{IU}$ of DL- $\alpha$-tocopherol at weekly intervals starting at $3 \mathrm{wk}$ before calving decreased the incidence of RFM and stillbirths and improved P/AI at first and all inseminations and decreased the interval from calving to pregnancy.

Substantial evidence from the literature exists of the importance of adequate concentrations of $\alpha$-tocopherol in blood and the role of supplemental vitamin E during the transition period on peripartum health in dairy cattle. First, low circulating concentrations of $\alpha$-tocopherol have been associated with increased incidence of RFM (LeBlanc et al., 2004; Qu et al., 2014). LeBlanc et al. (2004) observed a reduction of $21 \%$ in the risk of RFM for every $1 \mu \mathrm{g} / \mathrm{mL}$ increase in serum concentration of $\alpha$-tocopherol in prepartum cows. $\mathrm{Qu}$ et al. (2014) demonstrated that cows with RFM had consistently less $\alpha$-tocopherol in serum than unaffected cows. Similar to the findings of LeBlanc et al. (2004) and $\mathrm{Qu}$ et al. (2014), it was observed that cows with low concentrations of $\alpha$-tocopherol prepartum had increased risk of RFM. As anticipated, a decline in concentrations of $\alpha$-tocopherol in serum was observed as cows approached calving, which is consistent with previous reports (Weiss et al., 1992; Goff et al., 2002; Bouwstra et al., 2010b) and most likely related to a de- crease in DMI and an increased shunting of tocopherol into colostrum (Goff et al., 2002).

Strong evidence exists that dietary supplementation of vitamin $\mathrm{E}$ prepartum decreases the incidence of peripartum diseases, particularly in cows of marginal vitamin $\mathrm{E}$ status or when Se in the diet is limiting. A single injection of $680 \mathrm{IU}$ of vitamin E and $50 \mathrm{mg}$ of Se administered to cows fed diets containing $500 \mathrm{IU}$ of supplemental vitamin E per day tended to decrease the incidence of RFM from 10.1 to 3.1\% (Aréchiga et al., 1994). Although LeBlanc et al. (2002) did not observe a benefit of a single s.c. injection with 3,000 IU of vitamin $\mathrm{E}$ administered to dairy cows 4 to $10 \mathrm{~d}$ prepartum, the same authors demonstrated that subgroups of cows with marginal vitamin E prepartum had a reduction in RFM after treatment. Erskine et al. (1997) also showed that administration of 3,000 IU of vitamin $\mathrm{E}$ 8 to $14 \mathrm{~d}$ prepartum decreased the incidence of RFM from 12.5 to $6.4 \%$. On the other hand, Bouwstra et al. (2010b) related detrimental effects of oral supplementation with 3,000 IU of vitamin E during the dry period on incidence of mastitis. In the work by Bouwstra et al. (2010b), high circulating vitamin E at study enrollment combined with high supplementation of vitamin E may have either overcharged the vitamin E oxidative stress cascade or overinhibited the production of ROS within cells because of excessive vitamin E. In the current study, cows had marginal serum $\alpha$-tocopherol at enrollment, and weekly administration of 1,000 IU of vitamin $\mathrm{E}$ caused a major reduction in the incidence of RFM, from 20.1 to $13.5 \%$. Despite the benefits of administering injectable vitamin $\mathrm{E}$ in reducing RFM, the incidences in the study herds were still above values typically reported in North American dairy farms (7.4\%; Chapinal et al., 2011).

The mechanisms by which supplemental vitamin $\mathrm{E}$ and adequate blood $\alpha$-tocopherol improve peripartum health, and, in particular, decrease the risk of RFM, are not fully elucidated. Vitamin $\mathrm{E}$ is a lipophilic molecule found mainly in cellular membranes that inhibit lipid peroxidation by reacting and neutralizing lipid peroxyl radicals (Wagner et al., 1996). When cows are supplemented with vitamin E prepartum, tissues, including leukocytes, have increased concentrations of tocopherol (Weiss et al., 1992), which is thought to improve the function of PMNL (Hogan et al., 1992). In fact, supplementation with vitamin E prepartum not only increased serum and the cellular $\alpha$-tocopherol (Weiss et al., 1992), but it also increased fast-acting antioxidants (Miller and Brzezinska-Slebodzinska, 1993), suggesting effects of tocopherol on multiple pools of cellular antioxidants. The increased antioxidant status of peripartum cows seems to be linked to improved immune competence, which likely plays a role in improving fetal 
membrane shedding immediately after calving (Kimura et al., 2002). Higher levels of oxidative stress 2 wk before calving are related, for example, to increased incidence of clinical mastitis (Bouwstra et al., 2010a). Improved immune-cell function, through either antioxidant effects or other cellular signaling pathways activated by $\alpha$-tocopherol, is likely to underlie the reduction in RFM after vitamin E supplementation.

Upon parturition, the immune system of the dam immediately attacks the remnants of fetal tissues, and in cattle, RFM is thought to arise from failure of the mechanisms of immune-mediated rejection of fetal tissues by the maternal immune system. Chemoattractant molecules recognized by the immune cells of the dam promote chemotaxis of leukocytes toward cotyledonary tissues (Gunnink, 1984a). Indeed, inability of cotyledonary tissues to attract leukocytes either before, at, or after calving has been observed in cows that develop RFM (Gunnink, 1984a,b; Heuwieser and Grunert, 1987). Near the time of calving, major histocompatibility complex class I antigens are expressed on the placenta, which is thought to activate an immune-mediated rejection of the placental tissues (Davies et al., 2004). Evidence from studies evaluating major histocompatibility complex class I between calf and dam clearly indicate that compatibility between maternal and fetal major histocompatibility complex class I molecules elicits a failure by the immune system of the dam to reject the fetal membranes (Benedictus et al., 2012). The inability of the immune system to recognize fetal antigens and to reject the placenta increases the risk of RFM (Davies et al., 2004; Benedictus et al., 2012). As part of the immune response against placental antigens, PMNL migrate to the placentomes and release proteolytic enzymes such as metalloproteinases that facilitate the degradation of collagen that attaches the maternal to the fetal components of the placenta. In cattle, detachment of the placenta has been linked with collagenolysis and proteolysis (Gross et al., 1985), processes induced by immune cells, and collagenase administration via the umbilical artery results in placental detachment in dairy cows (Eiler and Hopkins, 1993). Therefore, compromised function of PMNL and other immune cells (Kimura et al., 2002), which is often associated with inadequate concentrations of $\alpha$-tocopherol (Hogan et al., 1992), is thought to increase the risk of RFM because of the less robust immune response against fetal placental antigens.

One of the risk factors for RFM is an increase in circulating cortisol in the days preceding calving (Peter and Bosu, 1987; Wischral et al., 2001). However, although average circulating cortisol concentrations increase around parturition in dairy cattle, many cows, particularly cows without RFM, show little change in circulating cortisol during the parturition process (Peter and Bosu, 1987). It is also well established that an elevation in plasma corticosteroids is known to suppress leukocyte function in cattle (Roth et al., 1982). Thus, the increase in circulating cortisol between 2 wk and 1 wk before calving in the control cows is consistent with previous studies (Peter and Bosu, 1987; Wischral et al., 2001) and consistent with a link between circulating cortisol and risk of RFM. Consistent with this idea, we demonstrated that treatment with injectable vitamin E decreased the elevation in serum cortisol in the week preceding calving and the incidence of RFM. Others also have shown that treatment with a combination of injectable vitamin $\mathrm{E}$ and $\mathrm{Se}$ or feeding vitamin $\mathrm{E}$ attenuates the cortisol response in cattle (Gupta et al., 2005) and in rodents (Watson and Petro, 1982). Data on broilers indicated that supplementation with vitamin $\mathrm{E}$ decreased corticosterone content in adrenal glands in response to ACTH injections (Taniguchi et al., 2001). Although the precise link between vitamin E and cortisol has not been definitively established, it has been suggested that ROS may alter steroidogenesis, through peroxidative inactivation of specific steroidogenic enzymes (Miller and Brzezinska-Slebodzinska, 1993). For example, in vitro studies in humans have shown that when the level of microsomal vitamin $\mathrm{E}$ in the adrenal was decreased, 3 3 -hydroxysteroid dehydrogenase-isomerase and 2l-hydroxylase activity were more resistant to inactivation compared with $17 \alpha$-hydroxylase and $17,20-$ lyase activity (Takayanagi et al., 1986). This could favor cortisol production, instead of $\mathrm{C}_{19}$ steroid synthesis. Collectively, these data indicate that immunosuppression around parturition, which could be related to elevations in circulating cortisol and further enhanced by lack of adequate vitamin $\mathrm{E}$ intake, increases the risk of RFM. Thus, the mechanisms that underlie the benefit of supplemental vitamin E on RFM likely involve improvements in cell-mediated immune function and a reduction in plasma cortisol around calving.

Interestingly, cows in VitE had a marked reduction in the incidence of stillbirth. Similar to our study, an extensive randomized study in 21 herds in Sweden reported that prepartum supplementation with vitamin $\mathrm{E}$ caused a $62 \%$ reduction in the odds of stillbirth (Waller et al., 2007). Inadequate vitamin E status can increase the risk of tissue lipid peroxidation, and vitamin $\mathrm{E}$ and Se deficiency are known to cause myocardial lesions that can increase calf mortality (Murray et al., 2008). In rats, administration of corticosteroids increased pup mortality, but this negative effect was reversed by treatment with vitamins E and C (Niu et al., 2013). Hartfield et al. (2000) reviewed the literature on lamb survival and concluded that supplemental vitamin $\mathrm{E}$ to pregnant ewes improved perinatal survival and health 
of lambs. A recent study examined the micronutrient concentrations in the liver of stillborn beef calves in western Canada and found that the most common deficiencies were magnesium, vitamin $\mathrm{A}$, and vitamin E (Waldner and Blakley, 2014). Thus, vitamin E deficiency is likely to underlie an increase in risk of stillbirth and calf mortality in certain herds. This could be the result of lipid peroxidation and muscle lesions, including myocardial lesions. Alternatively, inadequate vitamin $\mathrm{E}$ could lead to inadequate placental function and increased fetal mortality near the time of parturition. This intriguing possibility remains to be experimentally tested but could provide a link between the reduction in RFM and stillbirth in cows supplemented with vitamin $\mathrm{E}$ during late gestation.

Supplementing cows with injectable vitamin E prepartum improved reproductive performance. Interval to pregnancy was decreased, and all of this benefit was the result of improved P/AI, primarily because of decreased pregnancy loss. Interval to first AI and insemination rate were not affected by treatment, and the lack of differences were attributed to the reproductive programs implemented in which the estrous cycle was manipulated by protocols for fixed times AI in cows not detected in estrus. Therefore, the reduction in interval to pregnancy in VitE cows was the result of improved $\mathrm{P} / \mathrm{AI}$ and decreased pregnancy loss. Supplementation with vitamin $\mathrm{E}$ has been shown to improve fertility in dairy cattle in some studies. Aréchiga et al. (1994) reported an improvement in reproductive performance after administration of injectable vitamin $\mathrm{E}$ to dairy cows during late gestation. The same group (Aréchiga et al., 1998) reported a reduction in the interval between calving and pregnancy of approximately $14 \mathrm{~d}$ and increased $\mathrm{P} / \mathrm{AI}$ at second service in cows supplemented with 500 $\mathrm{mg}$ of vitamin $\mathrm{E}$ and $50 \mathrm{mg}$ of Se in an injectable form at $30 \mathrm{~d}$ postpartum. The observation that postpartum supplementation only benefited cows at second service (Aréchiga et al., 1998), whereas prepartum supplementation had benefits at first service (Aréchiga et al., 1994; current study), suggests a delayed effect of vitamin E supplementation on fertility. This intriguing possibility remains to be specifically tested in future experiments. Several mechanisms have been proposed by which antioxidants, including vitamin E, might improve reproduction in cattle (Miller and Brzezinska-Slebodzinska, 1993), and they are mostly based on the scavenging effects of tocopherol against ROS that might interfere with steroidogenesis or embryo development. One of the models to study the effects of vitamin E supplementation on reproduction has been heat stress. Cows under heat stress are expected to have increased oxidative stress (Bernabucci et al., 2002) because cells exposed to high temperatures have increased concentration of ROS and products of lipid peroxidation (Wang et al., 2013). In spite of the well-characterized benefits of vitamin $\mathrm{E}$ on reducing oxidative damage to cells (Olcott and Emerson, 1937; Miller and Brzezinska-Slebodzinska, 1993; Wagner et al., 1996), the benefits of strategic vitamin $\mathrm{E}$ supplementation to improve fertility of cows under heat stress has been inconsistent. Ealy et al. (1994) did not observe a benefit on $\mathrm{P} / \mathrm{AI}$ of injectable supplemental vitamin $\mathrm{E}$ to cows receiving or not strategic cooling around breeding. Another possibility is that inadequate tocopherol might limit normal development of uterine function by affecting the normal placental and uterine vascular network (Kasimanickam et al., 2012). Alternatively, vitamin E could have effects on follicles that develop during the late prepartum or early postpartum period and potentially alter the future fertility of these developing oocytes, similar to the proposed effects of negative energy balance on developing oocytes (Leroy et al., 2008). An alternative possibility is that positive effects of supplemental vitamin E could be mediated through effects on postpartum health such as decreased incidence of RFM and stillbirths, which are known depressors of estrous cyclicity and P/AI (Santos et al., 2010). Cows that have calving-related problems such as RFM and stillbirths are at a much greater risk of developing metritis and purulent vaginal discharge in the weeks following calving (Dubuc et al., 2010). These uterine problems cause marked depressions to $\mathrm{P} / \mathrm{AI}$ (Dubuc et al., 2010), and the negative effect on fertility is, to a large extent, mediated by the increased risk of pregnancy loss (Santos et al., 2010), similar to what was observed in control cows in the current study. In fact, the positive effect of supplementation with vitamin $\mathrm{E}$ on pregnancy rate was similar to that observed for cows not diagnosed with RFM compared with those diagnosed with RFM.

Supplementation with vitamin E during the prepartum period did not affect milk production in the subsequent lactation, in spite of the decreased incidence of RFM and stillbirth. Another study has also observed no change in milk yield after supplementation with vitamin E, in spite of reducing the risk of mastitis (Weiss et al., 1997).

\section{CONCLUSIONS}

Dairy cows receiving less than $50 \%$ of the dietary recommendations of vitamin $\mathrm{E}$ had marginal concentrations of $\alpha$-tocopherol in serum, and decreased serum $\alpha$-tocopherol concentrations at study enrollment were associated with increased risk of RFM and decreased subsequent reproductive performance. Supplementing these cows with weekly injections of $1,000 \mathrm{IU}$ of $\alpha$-tocopherol in the last 3 wk of gestation markedly 
decreased the incidence of RFM and stillbirths, and improved reproductive performance during the first 200 DIM. The present study confirms the findings of others that feeding dairy cows less than 500 IU of vitamin E per day during the last weeks of gestation results in an inadequate concentration of plasma $\alpha$-tocopherol that compromises peripartum health and subsequent reproduction. Furthermore, the use of weekly injectable vitamin $\mathrm{E}$ for 3 wk before parturition proved efficacious in reducing the incidence of RFM, reducing stillbirths, and improving subsequent reproduction in dairy cows.

\section{ACKNOWLEDGMENTS}

The authors thank the owners and staff of Queima Ferro Farm (Pitangui, MG, Brazil), Santo Antonio Farm (Matozinhos, MG, Brazil), and Rasip Farm (Vacaria, RS, Brazil) for the use of their cows and facilities. The injectable vitamin $\mathrm{E}$ product was donated by Laboratórios Bravet (Rio de Janeiro, RJ, Brazil). We also thank Guilherme Nogueira and Carla Bittar for helping with some of the hormone assays. This project was funded by a grant from the São Paulo Research Foundation (FAPESP) \#2012/21066-7. We also thank CNPq of Brazil for the fellowship to G. C. S. Pontes.

\section{REFERENCES}

Aréchiga, C. F., O. Ortíz, and P. J. Hansen. 1994. Effect of prepartum injection of vitamin $\mathrm{E}$ and selenium on postpartum reproductive function of dairy cattle. Theriogenology 41:1251-1258.

Aréchiga, C. F., S. Vásquez-Flores, O. Ortíz, J. Hernandez-Cerón, A. Porras, L. R. McDowel, and P. J. Hansen. 1998. Effect of injection of $\beta$-carotene or vitamin $\mathrm{E}$ and selenium on fertility of lactating dairy cows. Theriogenology 50:65-76.

Arizmendi, D., L. McDowell, T. Sinclair, P. Mislevy, F. Martin, and N. Wilkinson. 2005. $\alpha$-Tocopherol and $\beta$-carotene concentrations in four tropical grasses as affected by increasing day length. Pages 39-40 in Florida Beef Report. Univ. Florida, Gainesville.

Arnaud, J., I. Fortis, S. Blachier, D. Kia, and A. Favier. 1991. Simultaneous determination of retinol, alpha-tocopherol and beta-carotene in serum by isocratic high performance liquid chromatography. J. Chromatogr. 572:103-116.

Benedictus, L., A. J. Thomas, R. Jorritsma, C. J. Davies, and A. P. Koets. 2012. Two-way calf to dam major histocompatibility class I compatibility increases risk for retained placenta in cattle. Am. J. Reprod. Immunol. 67:224-230.

Bernabucci, U., B. Ronchi, N. Lacetera, and A. Nardone. 2002. Markers of oxidative status in plasma and erythrocytes of transition dairy cows during hot season. J. Dairy Sci. 85:2173-2179.

Bouwstra, R. J., M. Nielen, J. R. Newbold, E. H. J. M. Jansen, H. F. Jelinek, and T. van Werven. 2010a. Vitamin E supplementation during the dry period in dairy cattle. Part II: Oxidative stress following vitamin E supplementation may increase clinical mastitis incidence postpartum. J. Dairy Sci. 93:5696-5706.

Bouwstra, R. J., M. Nielen, J. A. Stegeman, P. Dobbelaar, J. R. Newbold, E. H. J. M. Jansen, and T. van Werven. 2010b. Vitamin E supplementation during the dry period in dairy cattle. Part I: Adverse effect on incidence of mastitis postpartum in a double-blind randomized field trial. J. Dairy Sci. 93:5684-5695.

Brzezinska-Slebodzinska, E., J. K. Miller, J. D. Quigley, J. R. Moore, and F. C. Madsen. 1994. Antioxidant status of dairy cows supple- mented prepartum with vitamin E and selenium. J. Dairy Sci 77:3087-3095.

Chapinal, N., M. Carson, T. F. Duffield, M. Capel, S. Godden, M. Overton, J. E. P. Santos, and S. J. LeBlanc. 2011. The association of serum metabolites with clinical disease during the transition period. J. Dairy Sci. 94:4897-4903.

Davies, C. J., J. R. Hill, J. L. Edwards, F. N. Schrick, P. J. Fisher, J. A. Eldridge, and D. H. Schlafer. 2004. Major histocompatibility antigen expression on the bovine placenta: Its relationship to abnormal pregnancies and retained placenta. Anim. Reprod. Sci 82-83:267-280.

Dubuc, J., T. F. Duffield, K. E. Leslie, J. S. Walton, and S. J. LeBlanc. 2010. Risk factors for postpartum uterine diseases in dairy cows. J. Dairy Sci. 93:5764-5771.

Ealy, A. D., C. F. Aréchiga, D. R. Bray, C. A. Risco, and P. J. Hansen. 1994. Effectiveness of short-term cooling and vitamin $\mathrm{E}$ for alleviation of infertility induced by heat stress in dairy cows. J. Dairy Sci. 77:3601-3607.

Eiler, H., and F. M. Hopkins. 1993. Successful treatment of retained placenta with umbilical cord injections of collagenase in cows. J. Am. Vet. Med. Assoc. 203(Suppl. 3):436-443.

Erskine, R. J., P. C. Bartlet, T. Herdt, and P. Gaston. 1997. Effect of parenteral administration of vitamin $\mathrm{E}$ on health of periparturient dairy cows. J. Am. Vet. Med. Assoc. 211(Suppl. 4):466-469.

Goff, J. P., and R. L. Horst. 1997. Physiological changes at parturition and their relationship to metabolic disorders. J. Dairy Sci 80:1260-1268.

Goff, J. P., K. Kimura, and R. L. Horst. 2002. Effect of mastectomy on milk fever, energy, and vitamins A, E and $\beta$-carotene at parturition. J. Dairy Sci. 85:1427-1436.

Gross, T. S., W. F. Williams, J. E. Manspeaker, and E. Russek. 1985. In vitro proteolytic activity of the late pregnant and peripartum bovine placenta. J. Anim. Sci. 61(Suppl. 1):391-392.

Gunnink, J. W. 1984a. Influence of dilution on the chemotactic properties of cotyledon suspensions. Vet. Q. 6(Suppl. 2):57-59.

Gunnink, J. W. 1984b. Retained placenta and leucocytic activity. Vet. Q. 6(Suppl. 2):49-51.

Gupta, S., H. Kumar, and J. Soni. 2005. Effect of vitamin E and selenium supplementation on concentrations of plasma cortisol and erythrocyte lipid peroxides and the incidence of retained fetal membranes in crossbred dairy cattle. Theriogenology 64:12731286

Hartfield, P. G., J. T. Daniels, R. W. Kott, D. E. Burgess, and T. J. Evans. 2000. Role of supplemental vitamin E in lamb survival and production: A review. J. Anim. Sci. 77:1-9.

Heuwieser, W., and E. Grunert. 1987. Significance of chemotactic activity for placental expulsion in cattle. Theriogenology 27:907912.

Hogan, J. S., W. P. Weiss, D. A. Todhunter, K. L. Smith, and P. S. Schoenberger. 1992. Bovine neutrophil responses to parenteral vitamin E. J. Dairy Sci. 75:399-405.

Johnson, M. M., and J. P. Peters. 1993. Technical note: An improved method to quantify nonesterified fatty acids in bovine plasma. J. Anim. Sci. 71:753-756.

Kasimanickam, R. K., V. R. Kasimanickam, G. J. Haldoson, and A. Tibary. 2012. Effect of tocopherol supplementation during last trimester of pregnancy on mRNA abundances of interleukins and angiogenesis in ovine placenta and uterus. Reprod. Biol. Endocrinol. 10:4

Kimura, K., T. T. Reinhardt, M. E. Kehrli Jr., and T. A. Reinhardt. 2002. Decreased neutrophil function as a cause of retained placenta in dairy cattle. J. Dairy Sci. 85:544-550.

LeBlanc, S. J., T. F. Duffield, K. E. Leslie, K. G. Bateman, J. TenHag, J. S. Walton, and W. H. Johnson. 2002. The effect of prepartum injection of vitamin $\mathrm{E}$ on health in transition dairy cows. J. Dairy Sci. 85:1416-1426.

LeBlanc, S. J., T. H. Herdt, W. M. Seymour, T. F. Duffield, and K E. Leslie. 2004. Peripartum serum vitamin E, retinol, and betacarotene in dairy cattle and their associations with disease. J. Dairy Sci. 87:609-619. 
Leroy, J. L., A. Van Soom, G. Opsomer, I. G. Goovaerts, and P. E. Bols. 2008. Reduced fertility in high-yielding dairy cows: Are the oocyte and embryo in danger? Part II. Mechanisms linking nutrition and reduced oocyte and embryo quality in high-yielding dairy cows. Reprod. Domest. Anim. 43:623-632.

Machlin, L. J., and A. Bendich. 1987. Free radical tissue damage: Protective role of antioxidant nutrients. Fed. Am. Soc. Exp. Biol. 1:441-445.

Miller, J. K., and E. Brzezinska-Slebodzinska. 1993. Oxidative stress, antioxidants, and animal function. J. Dairy Sci. 76:2812-2823.

Murray, R. D., A. J. Williams, and I. M. Sheldon. 2008. Field investigation of perinatal mortality in Friesian cattle associated with myocardial degeneration and necrosis. Reprod. Domest. Anim. 43:339-345.

Niu, Y., E. A. Herrera, R. D. Evans, and D. A. Giussani. 2013. Antioxidant treatment improves neonatal survival and prevents impaired cardiac function at adulthood following neonatal glucocorticoid therapy. J. Physiol. 591:5083-5093.

NRC. 2001. Nutrient Requirements of Dairy Cattle. 7th rev. ed. Natl. Acad. Sci., Washington, DC.

Olcott, H. S., and O. H. Emerson. 1937. Antioxidant properties of tocopherols. J. Am. Chem. Soc. 59:1008-1009.

Peter, A. T., and W. T. K. Bosu. 1987. Peripartal endocrine changes associated with retained placenta in dairy cows. Theriogenology 28:383-394.

Qu, Y., A. N. Fadden, M. G. Traber, and G. Bobe. 2014. Potential risk indicators of retained placenta and other diseases in multiparous cows. J. Dairy Sci. 97:4151-4165.

Roth, J. A., M. L. Kaeberle, and W. H. Hsu. 1982. Effects of ACTH administration on bovine polymorphonuclear leukocyte function and lymphocyte blastogenesis. Am. J. Vet. Res. 43:412-416.

Santos, J. E. P., R. S. Bisinotto, E. S. Ribeiro, F. S. Lima, L. F. Greco, C. R. Staples, and W. W. Thatcher. 2010. Applying nutrition and physiology to improve reproduction in dairy cattle. Soc. Reprod. Fertil. Suppl. 67:387-403.

Takayanagi, R., K. I. Kato, and H. Ibayashi. 1986. Relative inactivation of steroidogenic enzyme activities of in vitro vitamin E- depleted human adrenal microsomes by lipid peroxidation. Endocrinology 119:464-469.

Taniguchi, N., A. Ohtsuka, and K. Hayashi. 2001. A high dose of vitamin E inhibits adrenal corticosterone synthesis in chicken treated with ACTH. J. Nutr. Sci. Vitaminol. (Tokyo) 47:40-46.

Wagner, B. A., G. R. Buettner, and C. P. Burns. 1996. Vitamin E slows the rate of free radical-mediated lipid peroxidation in cells. Arch. Biochem. Biophys. 334:261-267.

Waldner, C. L., and B. Blakley. 2014. Evaluating micronutrient concentrations in liver samples from abortions, stillbirths, and neonatal and postnatal losses in beef calves. J. Vet. Diagn. Invest. 26(Suppl. 3):376-389.

Waller, K. P., C. Hallén Sandgren, U. Emanuelson, and S. K. Jensen. 2007. Supplementation of RRR- $\alpha$-tocopherol acetate to periparturient dairy cows in commercial herds with high mastitis incidence. J. Dairy Sci. 90:3640-3646.

Wang, Z., F. Cai, X. Chen, M. Luo, L. Hu, and Y. Lu. 2013. The role of mitochondria-derived reactive oxygen species in hyperthermiainduced platelet apoptosis. PLoS ONE 8(Suppl. 9):e75044.

Watson, R. R., and T. M. Petro. 1982. Cellular immune response, corticosteroid levels and resistance to Listeria monocytogenes and murine leukemia in mice fed a high vitamin E diet. Ann. N. Y. Acad. Sci. 393:205-210.

Weiss, W. P., J. S. Hogan, K. L. Smith, D. A. Todhunter, and S. N. Williams. 1992. Effect of supplementing periparturient cows with vitamin $\mathrm{E}$ on distribution of $\alpha$-tocopherol in blood. J. Dairy Sci. 75:3479-3485.

Weiss, W. P., J. S. Hogan, D. A. Todhunter, and K. L. Smith. 1997. Effect of vitamin E supplementation in diets with a low concentration of selenium on mammary gland health of dairy cows. J. Dairy Sci. 80:1728-1737.

Wischral, A., I. T. N. Verreschi, S. B. Lima, L. F. Hayashi, and R. C. Barnabe. 2001. Pre-parturition profile of steroids and prostaglandin in cows with or without foetal membrane retention. Anim. Reprod. Sci. 67:181-188. 